\title{
Causes and Effects of Staff Turnover in the Academic Development Centre: A Case of a Historically Black University in South Africa
}

\section{Chabaya Owence}

University of Limpopo, owence.chabaya@ul.ac.za

Tshephe Geoffrey Pinagase

University of South Africa, tshepgp@unisa.ac.za

Molotsi Matshidiso Mercy

University of Limpopo, matshidiso.molotsi@ul.ac.za

\section{Doi:10.5901/mjss.2014.v5n11p69}

\section{Abstract}

The high turnover of staff is unhealthy for the smooth running of institutions since it affects the growth, profitability and customer satisfaction whenever it occurs in the workplace. However, some employers see the process of staff leaving and being replaced as a natural and inevitable feature of the industry. This study focused on establishing the causes and effects of high staff turnover at an Academic Development Centre in one institution of higher learning in South Africa. The study specifically focused on the main causes of and the ground realities of the problem of employee turnover on sustainable growth of the organization. This was a qualitative study which adopted descriptive survey research design. Data was collected through interviews and narratives and respondents were the 6 staff members who resigned in 2012 from the institution under study as well as the remaining 8 staff members in the centre. The study revealed that, poor working conditions where employees were given short term contracts for a long period led to uncertainty at the job. More so, the understaffing as well as undefined job descriptions where one ended up being a jack of all trades led to job insecurity was also pointed out as a push factor. In addition, lack of academic promotion prospects was also found to be a push factor in the departure puzzle of staff. The study therefore recommended that, the management should improve the working conditions for the employees and finalise the proposed unit structure. Finally, the need to establish a promotion system that would motivate staff other than monetary remunerations was also recommended.

Keywords: staff turnover, academic Development Practitioners, Academic Development Centres' Higher Education,

\section{Introduction and Background of Study}

Continuous academic development of staff in any organization promotes quality and relevance of the organization. Clegg (2009) states that Academic Development (AD) has emerged as an 'important' Unit or Centre in Higher Education internationally over the past 40 years, and has shaped discourse in teaching and learning in Universities. In South African, AD is now gaining popularity in Higher Education landscape. Similar to UK Higher Education Institution, there is evidence of a steady growth in interest in learning and teaching in Higher Education in South Africa brought by the AD (Gosling 2001). However, most institutions of higher learning in the country do not have sufficient number of qualified and experienced Academic Development Practitioners (ADPS) to manage their units or centres. The few practitioners the country has are circulating around the 23 Universities in South Africa and while others are falling between the cracks, which leaves the country with very few Academic Development Practitioners (ADPs). Due to lack of enough ADPs, the Universities are experiencing high Exodus in these centres. It is not easy to get appropriately qualified staff for $A D$ and Gosling (2009) echoed this when he states that the Universities find it difficult to recruit suitable AD staff, particularly on filling vacancies and finding sufficiently experienced personnel. The University under study also fell-a-prey to this Higher Institution's crises when it lost six (6) out of 13 members that included the Executive Director and the Deputy Director of the Unit in one academic year. Thus, this paper investigated the causes of this exodus and the subsequent effects on the running of the AD centre. The paper discussions and focus was on reasons why the ADPs left the employment of the University, the workload for the remaining staff, and the effects or impact of the exodus to teaching and learning and on 
services rendered by the centre to the faculties.

\section{Literature Review}

\subsection{Academic Development in Higher Education}

Across the world, higher education institutions are confronting the challenge of how to enable ever larger numbers of students with increasingly diverse characteristics to succeed (CHE, 2004). In spite of these large numbers of students, universities are expected to create opportunities for their students to explore, think and grow, and in the end to live not only usefully but also creatively, responsibly and reflectively (Stanford 2012). As a way of enhancing student success, graduation rates and throughput rates, Academic Development Centres (ADC) or Academic Development Units (ADU) as it is referred to differently in different institutions were set up in almost all institutions of higher learning in South Africa. A broader definition of $A D$ encompasses more than professional development of staff. It can include support for and development of learning technologies, the production of learning materials (on-line or in hard copy), support for students (career advice, counselling, wellness programmes) and students' learning development (academic literacy, numeracy, study skills), quality assurance and enhancement, and many other specialist functions (Gosling 2009). The larger South African ADCs have a wide range of functions, including both learner support and learning development, which are typically not part of the responsibility of ADCs elsewhere in the world (Gosling 2009).

A function that has been central to the concept of 'academic development', as it has historically been understood in South Africa, is the provision of support for student learning development through extended studies programmes, workshops on literacy, numeracy and study skills, mentoring and supplementary instruction schemes. This provision relates to the specific historical circumstances of South Africa, post-Apartheid, with large numbers of students regarded as 'under-prepared' who are undertaking their higher education in a second or other language (Gosling 2009).

However, differing interpretations of the roles of such centres at different institution led to varying levels of support and respect for the centres in different institutions. Some institutions do not regard the value that the ADC/U is adding to different academic departments and some see the centres as competition. Yet AD Centres should be viewed as partners for academic departments for the success of academic work in the faculties and/or departments. Their role is to support and develop both the academic staff and students to ensure success. However, it is evident that there is high staff turnover in one institution. Derek (2006) in his study found out that the employees' turnover is positively associated with the organization inefficiency. Therefore this study examined the factors that caused high staff turnover in the ADC at one institution and the effects of the staff exodus on the efficiency of the centre.

\subsection{Staff turnover in institutions and organizations}

Employee turnover is the rotation of workers around the labour market; between firms, jobs and occupations; and between the states of employment and unemployment and retaining employees remains a primary concern for many organizations during days of intellectual property (Abbasi, 2000). One way to understand turnover is by explaining the difference between Push and Pull factors. 'Push' factors cause individuals to look for another job, for example, dissatisfaction with working conditions. 'Pull' factors draw employees towards another organisation (for example, higher salary or better benefits. In 2006 People in Aid research on why people stay and perform in an organization and why staff leaves the organization it was found out that for each individual there may be a number of inter connected push and pull factors for leaving or staying. The factors included presence or absence of good team, Challenge / variety; innovative culture; excessive workload; poor systems; better pay / terms and conditions elsewhere poor leadership; Lack of career opportunity and growth: burnout, disillusionment and frustration. This shows that there are various reasons which cause staff turnover and some may affect an employee simultaneously. Some of these reasons are presented below.

\subsection{Causes of staff turnover}

\subsubsection{Job satisfaction}

Job satisfaction has been found to be one case of staff turnover where employees having job dissatisfaction leave their current employer easily (Abdali, 2011; Mobley, 1977). The relationship between job satisfaction and employee turnover is reciprocal to each other and this relationship is high when unemployment rate is low in a society and similarly low when unemployment rate is high (Abdali, 2011; Spector 1997). 


\subsubsection{The organizational culture:}

The more the organization has the ability to elicit a sense of commitment on the part of employees, and its development of a sense of shared goals, among other factors, the more employees experience job satisfaction and in turn the less the turnover intentions and turnover rate (Kuria, Alice and Wanderi, 2012).

\subsubsection{The characteristics of the job:}

According to Taylor (2002), some jobs are intrinsically more attractive than others. A job's attractiveness will be affected by many characteristics, including its repetitiveness, challenge, danger, perceived importance, and capacity to elicit a sense of accomplishment ( Kuria, Alice and Wanderi, 2012). Such characteristics as short contracts may pause a danger of being out of employment within a short notice.

\subsubsection{Unrealistic expectations:}

Another factor is the unrealistic expectations and general lack of knowledge that many job applicants has about the job at the time that they receive an offer. When these unrealistic expectations are not realized, the worker becomes disillusioned and decides to quit (source if possible).

\subsubsection{The person}

In addition to the factors listed above, there are also factors specific to individual that can influence turnover rates. These include both personal and trait-based factors. Personal factors include things such as changes in family situation, a desire to learn a new skill or trade, or an unsolicited job offer. In addition to these personal factors, there are also trait-based or personality features that are associated with turnover as cited by Mobley (1977). These traits are some of the same characteristics that predict job performance and counterproductive behaviours such as loafing, absenteeism, theft, substance abuse on the job, and sabotage of employer's equipment or production (Kuria, Alice and Wanderi, 2012).

\subsubsection{Better pay elsewhere:}

Pay is defined as the wages, salary, or compensation given to an employee in exchange for services the employee performs for the organization (Kuria, Alice and Wanderi, 2012). Most employees feel that they are worth more than they are actually paid and there is a natural disparity between what people think they should be paid and what organizations spend in compensation. One of the most common reasons given by employees leaving their current employment is the availability of higher paying jobs (Wood and Macaulay, 1991). Gupta and Shaw (2001), argue pay as the most critical outcome of organizational membership for employees. On a similar note, Kusluvan (2003) also said one of the major causes of friction between the employers and their employees is a real or perceived lack of fairness in the distribution of wages. It is further argued that that when the difference becomes too great and another opportunity occurs, turnover can result ( Taylor, 2002).

According to Kusluvan (2003), there are two extreme approaches to the determination of wages. At one extreme, there is a total transparency in which every employee can know what everyone else earns while on the other end, are employers who not only keep secret what they pay each employee but also make a condition of employment that salaries are not to be discussed between staff. The latter may be another cause of employees leaving their jobs feeling that there is no fairness in terms of salaries and relate this to favouritism. Kusluvan (2003) concludes by stating that, it is vital to adopt a methodical system of evaluating jobs so that wages and salaries are fairly distributed to all.

\subsection{Effects of high staff turnover}

Labour turnover is significant to organization, individuals and management (Kuria, Alice and Wanderi, 2012). From the organizational perspective, labour turnover represents a significant direct cost in terms of recruiting, poor production practices and reduced standards as well as high replacement and training costs (Hiemstra, 1990). On a similar note, Fair (1992) suggests that, there are other costs associated with labour turnover which include separation costs (exit interviews and severance pay), recruitment costs (advertising and search fees), selection costs (interview and reference checking), hiring costs (induction and initial training), relocation expenses, uniforms and lost productivity costs associated with both 
the unfilled vacancy and the learning curve associated with the new employee. Indirect costs however are associated with decreased levels of employee motivation, absenteeism, tardiness leading to customer dissatisfaction and ultimately customer defection (Fair, 1992). Similarly, Sutherland (2000) said these replacement costs include for example, search of the external labour market for a possible substitute, selection between competing substitutes, induction of the chosen substitute, and formal and informal training of the substitute until he or she attains performance levels equivalent to the individual who quit. Turnover has many hidden or invisible costs affect the profitability of the organisation and customer service and satisfaction (Kemal, Din \& Qadir, 2002). Research estimates indicate that hiring and training a replacement worker for a lost employee costs approximately 50 percent of the worker's annual salary (Johnson et al., 2000).

\subsection{Importance of combating high turnover}

The provision of a high quality working environment with a range of employee-valued benefits may increase satisfaction levels and hence discourage turnover behaviours (Mobley, 1977). Turnover should always be monitored. It is a leading indicator to ensure that retention is not becoming an issue. Complacency can cause serious problems in eroding the good progress that has been developed previously (Abbasi, 2001). Measuring and monitoring turnover is essential to bringing the appropriate attention to the issue and taking constructive action. Understanding the employment climate is fundamental to developing and understanding of retention. Having acceptable targets; based on precise definitions of turnover that are meaning to the organization, help to bring the process clearly into focus. These are aimed at bringing the proper resources and attention to this critical issue so that action is taken. The senior management team should moreover accept the responsibility for managing retention (Abbasi, 2001).

\section{Context and Background of the Institution Under Study}

The institution under study has two campuses which joined together in 2005 as a result of the mergers effected by the government. One AD centre for the university was successfully formed. This centre comprised of the Executive Director with 6 Academic Development Practitioners (ADPs) and a secretary seating at one campus and the Deputy Director with 7 ADPs and a secretary seating at another campus. Although the two campuses are a long distance apart (about $300 \mathrm{~km}$ ), ADPs were supporting each other in terms of academic development work. One group from the other campus would help another group from another campus in facilitating workshops and training. At times, the two groups would run combined workshops and training. In the same year, 2012, the centre lost 8 members of staff, the Executive Director, the Deputy Director and 6 ADPs from both campuses. This created a big vacuum in the development and support of the academic staff in the institution.

\section{The Theoretical Framework}

\subsection{The Human capital theory and the Intellectual Capital Theory}

This study which sought to investigate the impact of staff turnover in an institution of higher learning is guided by the principles of intellectual capital theory. Intellectual capital is viewed as the key source of wealth creation and hence it is logical that firms pay close attention to effective management of such capital (Marti, 2007). The intellect is viewed as an intangible assert in an organization. Although intangible asserts cannot be touched, they can be identified and reasonably classified (Marti, 2007). In a similar note, Sveiby (2001) came up with three intangible assets in an organization and these are: assets of individual competence, assets of internal structure and assets of external structure.

Assets of individual competences refer to aspects such as education, experience, know-how, knowledge, skills, values and attitudes. The company does not own those assets, but the use of those assets is accessed by the company's hiring of employees. This asset is also known as human capital (Marti,2007). Human capital theory has been found to be appropriate in examining organizational-level consequences of voluntary staff turn-over (Dess and Shaw, 2001). "Human capital is the knowledge possessed by employees and is aggregated at the organizational level in terms of their combined competence and experience" (Massingham, 2008:27). In other words, the theory suggests that when an employee exits, it implies exiting of specific functional expertise, experience, skills and contacts. Such a situation produces two direct impacts namely; decreases organizational output and decreased organizational productivity (Droeg and Hoobler. 2003).

Assets of internal structure refers to the company's formal and informal organizational structure, working methods and procedures, research development systems, management systems and culture (Marti, 2007). Such assets are 
owned by the organization and some can be legally protected. This type of asset is also known as structural asset. However, voluntary exit of staff affects the stability of such assets. The third type of assets is the assets of external structure. This refers to the company's portfolio of customers (e.g. good will).and its relationship with outside stakeholders as well as its image. These assets are owned by the company and some can be legally protected. These assets are also known as relational assets. Although these assets are owned by the organization, their operational value and stability could be affected by staff turnover.

In short, intellectual capital theory points out some types of losses experienced by organizations due to voluntary exits and these include; lost human capital, lost social capital, lost structural capital and lost relational capital.

\section{The Problem}

The study sought to find out the causes of high staff turnover and effects on the remaining staff at an Academic Development Centre in one institution of learning in South Africa. Literature shows that staff turnover has some adverse effects on the operations of an organization. It is for this reason this study sought to look at the why the ADPs left the Institution. The study also considered the effects of this staff turnover on learning \& teaching development and support, and the general academic development of the University.

\section{Research Aim}

The aim of this paper was to investigate the factors causing the staff exiting at the Academic Development Unit at the University of Limpopo.

\section{Research Questions}

- What are the underlying factors leading to high staff turnover in the Academic Development centre?

- What is the impact of the staff exit on operations of the Academic Development at the institution?

- What could be done to retain staff members in the Academic Development Centre?

\section{Research Methodology}

\subsection{Research design}

The research is a case study which sought to find out factors that contribute to high staff turnover in the Academic Development Centre at one university in South Africa. Anderson and Arsenault (2000) define case study as an investigation into a specific phenomenon within its real-life context. The case study allows intensive investigation (Lindeger, 2006: 460) of the exit of staff at the Academic Development Unit. This study is located in the qualitative paradigm and it adopted interpretive approach. Bogdan and Biklen (2003) point out that interpretive qualitative methodology affords researchers opportunity to get involved in particular settings under study because they are concerned with context. One of the advantages of qualitative interpretive methodology is that "it can reveal the nature of certain situations, settings, processes, relationships, systems or people" (Leeds and Ormond 2001: 148).

\subsection{Population and Sampling}

The study was confined to the Academic Development Centre in one institution of higher learning. All academic Development Practitioners who were in the Centre in 2012 were included in the sample. Thus the sample comprised of 6 member who left the centre in 2012 and 8 who remained in the centre in the same year. The purpose of choosing both those who left and those who remained in the centre was to find out from those who left the reasons for deciding to leave and also to find out effects of those departures from those who remained in the centre. The sampling technique used in this case is purposive because the researchers have selected groups of participants based on a specific purpose according to preselected criteria relevant to a particular research question (Teddie and Yu, 2007)

\subsection{Data Collection}

Data were collected through unstructured interviews and narratives, According to Welman, Kruger \& Mitchell (2005) 
unstructured interviews are in-depth interviews that are informal and allow the researcher to explore the area of interest. There is no lists of reformulated structured questions; the interviewee is allowed to freely talk about aspects that relate to the area that is researched. In-depth interview which is unstructured allows the researchers to explore sensitive and highly emotional issues that relate to the area of interest (Welman, Kruger \& Mitchell, 2005: 166).

Interviews were carried out with AD Practitioners who were still in the centre while those who had already left the centre were asked to write narratives of their experiences at the centre that led them to leave. This they did and sent the narratives via email since they were then scattered in many places in the country.

\subsection{Data Presentation and Analysis}

Collected data was arranged thematically into categories. The steps taken for thematic analysis were, "becoming familiar with data; generating initial codes; searching for themes; reviewing themes; defining and naming themes; and lastly producing the report" (Braun and Clarke, 2006:77). The data was grouped into the following two (2) identified themes namely, causes of the staff turnover and effects of the departure on the operations of the centre. The themes were further grouped into categories including; salary; job security, support from management and work environment.

\section{Discussions}

\subsection{Causes of the staff turnover}

From the data collected, job security is pointed out as the major reason for deciding to leave the Academic Development Centre. Lack of job security was also pointed out as a factor that caused high staff turnover in the centre. One respondent said "I was tired of being on short term contracts of 3 months or 6 months as this did not allow me to plan my life ahead. The moment I got this permanent one, I did not have to think twice". The same sentiments were echoed by another respondent who said that "being on short contracts, which were at times, renewed a few days before the expiry date or after the expiry date, gave me a lot of anxiety fearing to be out of employment any time. Therefore, I had to hunt for a better place so as to have a peace of mind" This finding is supported by Zuber, (2001) when he said, organisational instability has been shown to have a high degree of high turnover and Indications are that employees are more likely to stay when there is a predictable work environment and vice versa (Zuber, 2001). In a similar note, Alexander, Bloom and Nuchols.(1994) found out that in organizations where there was a high level of inefficiency there was also a high level of staff turnover. Therefore, in situations where organizations are not stable employees tend to quit and look for organisations where stability is the order of the day because with stable organisations they would be able to predict their career advancement.

The salary structure is also pointed out as another reason for departing . One respondent said, "My salary was not changing for some years and it was lower than that of some of my colleagues who are working in faculties and yet we have same qualifications and experience. So when I got this post with a higher salary and post level though same job, I could not help, but just to go for it." Griffeth et al. (2000) noted that pay and pay-related variables have a high effect on turnover when they concluded that when high performers are insufficiently rewarded, they quit. If jobs provide adequate financial incentives the more likely employees remain with organisation and vice versa.

Working conditions and lack of support from management, which includes growth and promotions is also pointed out as it led to frustrations. One participant said, "A person does not stay in an organization only for salary but one needs a better working environment". The respondents further alluded to the fact that there is no clear promotion line in AD job at this particular institution. One of the respondents states "we are trying so hard to improve our qualification so that we may be able to assists the academics with confidence and proper insight but the university does not recognise our development. We do not get any notch or promotion we have to wait for seniors to resign or retire and all of us fight for the position".

\subsection{Effects of the departure on the operations of the centre.}

The remaining participants pointed out that the departure of colleagues caused a lot of strain on them in the form of work overload. One said, " Due to the leaving of our colleagues, management take time to replace them and we end up being overloaded" The other one said, " The under-staffing in the centre makes up end up being jacks of all trades since there will be some roles to be carried out which are outside our areas of expertise. This frustrates us and at times we end up also contemplating to quit." One respondent also said, the institution takes about 12 to 18 months to replace a vacant 
post and this affects us due to work overload." Thus this mat affects the quality of work in the centre.

Lack of clear-cut promotion prospects in the centre was also pointed out as a reason for quitting. "I cannot get into a job and remain stagnant in that position all my life in terms of salary and level. I had to look for a department that recognizes one's qualifications and experience", said one respondent. The same sentiments were echoed by another respondent who said, "Everyone wants to progress in his/her carrier and this is rare in Academic Development centre". This shows that promotion prospects matter a lot to staff in Centres.

\section{Conclusions and Recommendations}

A number of factors were found to be the causes of the high turnover of staff in the centre. These included the issue of staying as contract workers for too long; lack of promotional prospects in the centre, salaries not being competitive with other institutions and lack of appreciation of the work in the centre by management.

Strategies on how to minimize employee turnover, confronted with problems of employee turnover, management has several policy options viz. changing (or improving existing) policies towards recruitment, selection, induction, training, job design and wage payment. Equally, employee turnover attributable to wage rates could be addressed by benckmarking on salaries with other institutions. Management should also show appreciation of the work in the centre and engage employees on issues that affect them. This way the employers would be in a position to note disgruntlements before they culminate into resignation.

\section{References}

Abassi H.K. , (2000). "'Turnover: the real bottom line"," Public Personnel Management, 2 (3), pp. 333-342,

Abdali, F. (2011). Impact of Employee Turnover on Sustainable Growth of Organization in Computer Graphics Sector of Karachi, Pakistan. Afro Asian Journal of Social Sciences 2 (4) 86-99.

Alexander, J. A., Bloom, J. R., \& Nuchols, B. A. (1994). Nursing turnover and hospital efficiency: An organization-level analysis. Industrial Relations Review, 33, 505-520.

Anderson, A., \& Arsenault, N., (2000). Research Methods. 2nd Edition. Philadelphia: Falmer Press.

Bogdan, C. R., \& Biklen S.K. (2003). Qualitative Research for Education: An Introduction to Theory and Methods.4th Edition. USA: Pearson Education Group Inc.

Braun, V., \& Clarke, V. (2006). Using thematic analysis in psychology. Qualitative Research in Psychology, 3 (2), 77-101.

Clegg, S. (2009): Forms of knowing and academic development practice. Studies in Higher Education, 34:4, 403-416

Council on Higher Education ( CHE) (2014). Framework for Institutional Quality Enhancement in the Second Period Quality Assurance. Council on Higher Education, Pretoria.

Derek, R. (2006). Turnover intentions: The mediation effects of job satisfaction, affective commitment and continuance commitment. Unpublished Masters Thesis, University of Waikato.

Dess, G.D., \& Shaw, J.D. (2001). "Voluntary turnover, social capital, and organizational performance", Academic Management Review. 26 (3): 446-456.

Droeg, S.B. \& Hoobler, J.M. (2003). Employee Turnover and tacit knowledge diffusion: A Network Perspective. Journal of Managerial Issues. 15(1) 50-64.

Fair, R. (1992) Australian Human Resource Management: Framework and practice, (2nd edition), McGraw-Hill, Sidney.

Gosling, D. (2001). Educational development units in the UK - what are they doing five years on?, International Journal for Academic Development, 6:1, 74-90

Gosling, D. Herman, J. (2009). Survey of Directors of Academic Development in South African Universities. http://stbweb02.stb.sun.ac.za/ct//documents/Report\%20on\%20Survey.pdf Accessed on 23/09 2013

Gupta, N.\& Shaw, J. (2001). Pay fairness and Employee outcomes. Exacerbation and attenuation effects of financial needs. Journal of Occupational and Organizational Psychology. 74 (3): 22-34.

Hiemstra, S.J. (1990) Employment policies and practices in the lodging industry. International Journal of Hospitality Management Volume 9 (3): 207-221.

Johnson J, Griffeth, RW, \& Griffin M (2000). "Factors discrimination functional and dysfunctional sales force turnover". Journal of Business, Industry and Marketing.15 (6): 399-415.

Kemal, A.R., M. Din and U. Qadir (2002), "Global Research Project: Pakistan Country

Report", Pakistan Institute of Development Economics, Islamabad.

Kuria, H.M., Alice, O.\& Wanderi, P.M. ( 2012) Assessment of Causes of Labour Turnover in Three and Five Star-Rated Hotels in Kenya. International Journal of Business and Social Science. 3 (15); 311-317.

Kusluvan, S. (2003) Multinational enterprises in tourism; A case study of Turkey. Unpublished doctoral dissertation, Strathclyde University, the Scottish Hotel School, Glascow.

Leeds, D. \& Ormod, J. 2001. Practical Research. 7th Edition. London: Prentice-Hall Inc. 
Lindeger, G. (2006) Research methods in clinical research. In Terre Blanche, M., Durrheim, K.,\& Painter, D. (Eds). Research in Practice ( $2^{\text {nd }}$ ed). (p. 455- 475). Cape Town: UCT Press.

Mart, J.M.V. (2007) In Search of an Intellectual Capital Comprehensive Theory. Electronic Journal of Knowledge Management, 5(2): 245-258.

Massingham, P. (2008) Measuring the impact of knowledge loss: more than ripples on a pond. Sage Publications. 29(5) $241-560$.

Mobley, W.H. (1977). Employee turnover, Causes, Consequences, and Control. Reading MA: Addison- Wesley.

Spector, P.E.(1997). Job Satisfaction: Application, assessment, cause and consequences. Thousand Oaks.CA: Sage Publications.

Stanford University ( 2012) The study of undergraduate Education at Stanford University. The Board of Trustees of the Leland Stanford Junior University.

Sutherland, J. (2000). "Job-to-job turnover and job to-non- employment movement" Personnel Review. 31(6): 710-721.

Sveiby, K.E. (2001) "Intellectual capital and knowledge management", [online], http://www.sveiby.com/articles/IntellectualCapital.html ( Retrieved on 18 March 2014)

Taylor, S. (2002) People and Organization Employee Resourcing. Prentice-Hall, Sidney; Australia.

Vale, I. (2010) A People In Aid and Emergency Capacity Building Project Horn of Africa Consortium Project, October 2010

Teddlie, C. and Yu, F. (2007). Mixed Methods Sampling: A Typology With Examples. Journal of Mixed Methods Research 1, (1), 77-100

Welman, C., Kruger, F., \& Mitchell, B. (2005). Research methodology (3rd ed). Cape Town: Oxford University Press.

Wood, R.H. \& Macaulay, J.F. (1991). Rx for turnover: retention programs that work", The Cornell Hotel, Restaurant Administration Quarterly, Vol. 30 (No.1), pp.79-90.

Zuber, A. (2001). A career in food service cons: high turnover, Nations Restaurant News, 35 (21):147-148. 